\title{
An Agenda for Research on Work and Class in the Post- socialist World
}

\begin{tabular}{|r|l|}
\hline Journal: & Sociology Compass \\
\hline Manuscript ID & SOCO-1121.R1 \\
\hline Wiley - Manuscript type: & Article \\
\hline Keywords: & $\begin{array}{l}\text { Organisations \& Work < Compass Sections, Labor History < Subjects, } \\
\text { Political Sociology < Compass Sections, Urban Sociology < Urban, Rural, } \\
\text { and Community Sociology < Sociology < Subjects, Sociology of Work and } \\
\text { Occupations < Work, Management, Occupations, and Organizations < } \\
\text { Sociology < Subjects, labor < Key Topics, class < Key Topics }\end{array}$ \\
\hline
\end{tabular}

\section{SCHOLARONE ${ }^{m}$ \\ Manuscripts}




\title{
An Agenda for Research on Work and Class in the Post-socialist World
}

\author{
'Arise, those who have been branded by a curse' \\ First line of the Russian version of the Internationale
}

Class is everywhere you look in the post-socialist world. The media are awash with stories about aspirational yet 'normal' 'European' lifestyles and the desirability of gated communities (Blinnikov et al. 2006; Polanska 2010), along with discussion of 'Communist-era' mentalities and outmoded concepts such as social justice and cohesion. Popular culture features 'low-lifes' and track-suit-clad petty criminals who serve as thinly veiled fantasies about dangerous lumpenization (Stenning 2005; Walker 2014). Against a backdrop of rising authoritarianism and populism in Eastern Europe, social protests are analysed for what they reveal about the growth of the middle class rather than a barometer of social distress. In scholarship there is often selective attention and selective invisibility (Ost 2009). In Russia, for example, liberal elites bemoan what they see as the political compliance of 'ordinary people' to the government's revanchist, chauvinistic authoritarianism. Pensioners, rural dwellers, and blue-collar workers in industrial 'hinterlands' are seen as dangerous classes of political conservatives (Zubarevich 2009, 2011), or worse, they are seen as easy prey to populist neo-nationalist movements (Kalb 2011: 7).

Just as once workers were the 'vanguard' of revolution and progress, now the 'creative class' (Kustarev 2013) is a talismanic 'locomotive of modernisation' and social transformation of these 
countries into 'normal' polities. 'Middle class' now stands for class studies more generally, with little acknowledgment that in CEE this group still remains a 'spirit seeking a social body' (Smolar 1996). Similarly, when it comes to work and organizations, scholarship often focuses on the rise of service industries, while the bread and butter of the socialist era - blue-collar work is rarely the object of research, except as a form of 'ruin-gazing' (High 2013), or as part of the study of urban renewal and deindustrialization (Mah 2012; Trubina 2013). All this suggests the first item on the agenda for class and work studies: the need for a more critical, reflective turn on the 'class blindness' of the academy which parallels the one-sided popular discourse on class in these societies. Both of these omissions are key to understanding the rise in populist politics and attitudes to inequality more generally.

With workers and others easily written off in this way, the road to modernization and democratization, and agency itself, is reserved for an ascendant middle-class, despite the continuing widespread reality of low-tech manufacturing and resource extraction underpinning many of the regions' economies. Indeed, many of these states have become sought-after sites of manufacturing because of the new consumer markets they offer to transnational corporations and their low wages. This indicates the second item for a renewed research agenda: work and class study reveal a crunch point at the meeting of unbridled neoliberal capital and disembedded labour between global North and South, understood both diachronically and spatially.

Postsocialist countries as diverse as Kazakhstan and Slovakia remain highly industrialised societies and are now productive sites of neocapitalism. Yet they sit between the global North and South lacking significant legacies of the social rights and privileges of Fordist labour, and yet offering a much longer working-class history, including of social mobility and negotiation with the state (memory of a social wage), than the South. Yet they share with the South the significant structural 
working-class power that the North now arguably has lost (Ness 2016); many post-socialist bluecollar contexts occur, like in the South, at crucial junctures of global supply chains.

Postsocialism, through the study of working classes, can also show the global North a version of its own past: offering a 'living' laboratory for oral historians and sociologists to study deindustrialisation as it happens now, as well as the renewed struggle for workers' rights in contexts where structural working-class power is still significant. It also indicates possible global North trajectories: the 'endgame' of extreme neoliberal reform in states where a social contract of sorts was formerly operative. Postsocialist workers are now at the heart of global working-class ${ }^{1}$ concerns, and the movements of global capital.

Finally, a last, but no means less important, agenda item is the need for more grounded and microfocussed portraits of class and work. This is the main approach suggested in this article - one that can help achieve all the other agenda aims. Grounding scholarship in the lived experience of 'ordinary ${ }^{2}$ people - providing 'emic' perspective - would shed light on many issues we still don't know enough about: how do people subsist and engage in household reproduction when wages are so low and the social state withdrawing or absent (Stenning et al. 2010)? How do memory and the mnemonic resources of the socialist past inflect current class identities and politics (Rivkin-Fish 2009, Straughn 2009)? How do transnational companies confront workers in the specific circumstances of postsocialism, and how are they in turn confronted by workers in an increasingly multi-polar, transnational capitalist environment (Hinz and Morris 2016)? What does work mean

\footnotetext{
${ }^{1}$ A members of a new global working-class, post-socialist workers must be included in a broadened perspective of the twenty-first century 'proletarian position' to include indentured labour of all kinds, lumpen formations, subsistencewage service and care workers and the informally working inhabitants of slums (cf. McMillan 2013: 128). All of these groupings exist in some form within postsocialist countries, in the global South and increasingly the global North. ${ }^{2}$ I use 'ordinary' people here to stress the radical potential of a class-inflected scholarship of postsocialism to uncover the connections in exploitation and concerns of many social groupings, and to underline the potential universality of the disenfranchised, disembedded conditions in postsocialism. It is a measure of the group-think within and beyond the academy that in a recent high-profile policy report I wrote on the former Soviet Union, the highly respected and influential global NGO requested I remove all 'class' references. When I replaced 'working-class' with 'ordinary people', this was also rejected and replaced by 'many people'.
} 
for ordinary people and what are the conflicting discourses of class and work (Walker 2014; Salmenniemi and Adamson 2014). We need a theoretically informed, yet grounded portrait of working- and newly-impoverished classes in the postsocialist world. These people, to paraphrase E. P. Thompson, are 'present at their own making' as a class. The fusion of postsocialist polities predicated on populism and semi-authoritarianism, extreme and rapid neoliberal transformation, and the withdrawal of the social state, mean a new kind of class identity and reality are in formation. However, that also means we should take note of how people are active in shaping their own roles, whether in exit, voice or loyalty, to those realities, and never passive recipients of neoliberalism.

\section{The hangover of communist-era sociology}

Communist regimes continually invoked class imagery as one tactic of legitimation. A superficial class lexicon was embedded in society — 'in legal texts, the media, at the workplace, and of course in academia, too' (Fabo 2015: 589). Despite this, 'sociology' was allergic to scientific inquiry into class issues. ${ }^{3}$ Regimes were afraid the results would show high inequality and that working life was just as miserable under socialism as capitalism. Indeed, some take the view that the sociology of class and inequality was largely impossible to practice - as a 'bourgeois pseudoscience', replaced by Marxism-Leninism (ibid). On the other hand, sociology was a policing science par excellence obsessively focussed on the 'concrete' empirical underpinning of the state's legitimacy by means of the accumulation of mass survey data Filippov (2013).

\footnotetext{
${ }^{3}$ Important exceptions include the work of Konrád and Szelényi (1979) who wrote on urban inequality and intellectuals in communist Hungary as a dominant stratum. In doing so they acknowledge the class exploitation of workers under socialism and the loss of any proletarian political role, as well as anticipating Bourdieusian notions of classed capital (Verdery et al. 2005). Current narratives of technocratic intelligentsia entitlement could be seen as an echo of such a position.
} 
This history has important implications for the present. While now conceptualising itself as needing to resist ideological control in the name of science, sociology is highly positivistic, surveybased, 'conservative and functionalist' (Fabo 2015: 591). The sociology of work remains 'theoretically timid' and hindered by 'historical limitations in qualitative research design' (Morrison and Bizyukov 2016: 2). Stratification and employment-based approaches adopted from Goldthorpe, and British sociology more generally have dominated, inflected by anticommunist politics (Drahokoupil 2015, Boyadjieva and Kabakchieva 2015). In some cases there is good reason for this - for example in linking rapid social and political change to the destruction of a relatively homogenous industrial working-class (Lazić and Svejić 2010). However, this means that the use of qualitative methods to reach marginalised groups is the exception, not the rule.

At the same time, there has been an 'anti-class' turn, where critical analyses of new property relations, systemic transformation and power structures in the post-socialist world is lacking (Ost and Gagyi 2015; Ost 2015). Now, freed of ideological constraints, native scholarship often resembles the revenge of the repressed, producing much work on the 'creative' middle classes and 'achievement ideology' often based on uncritical acceptance of the idea of successful imposition from above of a neoliberal order, and even embarrassment about adopting a class perspective (Helemäe and Saar 2015), or the idea that class analysis is no longer relevant to 'reflexive modernity' of postsocialism (Hass 2012). This gives the myth of postsocialist classlessness a relentlessly aggressive inflection in such contexts as the priority of civil society building over maintaining 'old fashioned' social protection (Fabo 2015: 590). In turn, the exacerbation of conflict and the polarization between capital and labour in post-socialist states is masked by sociological pre-occupation with elite agency, 'exclud[ing] subordinate classes, which in effect become the bewildered-silent and silenced- spectators of transformations that engulf them (Burawoy 2001: 1107). 
Finally, in authoritarian states like Russia and in Central Asia, urban and social movement studies focus more on the middle-classedness of metropolitan protests and pay less attention to industrial disputes outside the metropolises but which are equally bellwethers of change (Zubarevich 2009, Bibkov 2012, Grigoryeva 2015). More work is needed on alternative class experiences of the urban along the lines of recent scholarship in geography and history (e.g. Stenning et al. 2010, Marzec and Zysiak 2016, Pozniak 2014).

\section{The scholarly heritage of class-studies - communism as a laboratory in exploitation}

Despite the 'middle-classification' of class discourse in Eastern Europe as following similar, if more extreme lines as in W. Europe (Edwards et al. 2012), there have always been good reasons for sociologists and anthropologists to study the lived experience of work and workers. In the communist period scholarship about workers related mainly to studies of political engagement, resistance and (false) consciousness (e.g. Holubenko 1975). Anglophone scholars were keen to measure the political responses to increased exploitation and saw the working-class as a barometer of possible social discontent. The best work emerged from cross-fertilisation of history and sociology - indicating the potential for a holistic treatment of class in the present. In the later socialist period as Western scholars gained at least limited access, political historiography, anthropology, sociology and area studies all provided important insights into the extremely harsh life and economic burden the working-classes suffered, but due to the closed nature of the countries there was little empirically-based social science carried out. Haraszti’s work on Hungary (1977) was a classic 'native' sociology of atomizing and alienated factory life, but written from the point of view of the anti-communist intelligentsia. Michael Burawoy (1992) drew attention to the camaraderie of working-classes, identifying a grim solidarity despite, or because of their 
exploitation. The less mediated exploitation of communism meant that workers saw through ideology and developed a kind of negative (critical) class consciousness, despite supporting the broad aims of socialism. More recently, Hann (2006: 106) explores the theoretical and methodological potential of an anthropology-sociology conversation that would rethink the relationships between alienation, identification and work more generally - for example, in (post)socialist contexts of constrained consumption. This has implications for studying the lived experience of class in the present, where precarious work and lack of class mobility are pressing concerns.

Towards the end of the socialist period a conflicting picture emerged: On the one hand, studies of the 'growing assertiveness' of workers (Triska and Gati 1981) and the Solidarity movement in Poland, but elsewhere portraits of political atomized Soviet workers unequipped to take on a significant role in social or political transformation. While Labour historiography generally supported an atomization thesis, it added much in terms of trying to understand social change and the nature of control under socialism (Filtzer 1992, 1996; Kotkin 1995, Siegelbaum 1988, Siegelbaum and Suny 1994, Straus 1997), but was less confident in exploring social stratification beyond state-centric understandings (Edele 2007: 350).

More recently, scholars have pointed to the structural power of workers under socialism and after. Labour studies and sociology has explored the paradox of 'passivity' versus incipient class power (notably Crowley and Ost 2001, Clarke et al. 1995). Outhwaite (2007) reiterates points made by Burawoy (2001) on the importance of moving beyond an elite-agency approach where working classes are merely 'demobilized' (Eyal et al. 1998), to do better justice to the reality of antagonistic class relations after communism. In the historical context, sociology has recently also painted a 
more nuanced picture of the contested nature of the inner life of industrial socialism and its workers as more than the passive victims of state power (Kenney 1997, Pittaway 2012, Hornsby 2013).

An instructive example of early post-socialist grounded empirical scholarship exploring the complex meanings of workers' lifeworlds and structural positioning is the slender yet wide-ranging account of Russian factory workers by Sergei Alasheev (1995a, 1995b, Alasheev and Kiblitskaia 1996), a member of Simon Clarke's team. Alasheev's body of work on workers, stretching to a mere 90 pages, manages to accomplish a sensitive and deeply resonant portrait of change, yet the enduring social embeddedness of workers in the (post)-socialist factory. What emerges is an analysis paying enough attention to questions of agency, the state, exploitation and processes of self-exploitation, and class as an occupational ethnographic culture or status group, to satisfy even the toughest critics of insufficiently broad (and allowing for potential comparative) class analysis (Therborn 2002). In terms of anticipating a rebirth of empirically grounded, yet theoretically informed sociology, the themes of Alasheev's work serves as signposts for more recent scholarship. For example: how does work continue to serve as a powerfully anchoring source of identity, wellbeing, attachment and sense of possible autonomy? How does class intersect with gender? How do workers endure the loss of breadwinner status and security associated with the socialist period? Not to mention the loss of the enterprise as the source of the social wage, massive loss of purchasing power in their cash wages, enormous loss of status, demonization, even. Do workers in these states now have more in common with production-scapes in the Global South? Do practical skills and a long history of 'making do' mean that precarity is 'compensated' for by the informal economy and in DIY practices (Caldwell 2004: 29, Morris 2016)?

Similarly, while factories are dismembered and societies undergo demographic shocks, the spaces of factory towns and urban settlements do not disappear. Memory and place link to working-class 
identity as 'a sort of anti-museum' filled with absent presences (de Certeau 1984: 108). The spirit of class-based loyalties haunts many spaces and reveals itself in the meagre yet vital life practices of the marginalised and humiliated, revealing class-based resourcefulness. While use of the term 'resilience' too often becomes a way of naturalizing and therefore excusing neoliberal governmentality (Zebrowski 2013), and shifts risks formerly dealt with at the level of the social onto the 'adaptable' individual (Joseph 2013), another key to the relevance of class in postsocialism is the question of communities and individuals response to the incessant hailing by the model of the neoliberal self.

\section{Recent scholarship - three waves}

Despite its difficult history, there is renewed interest in work and class in the former socialist world. The previous section shows that there was always a small community of scholars working on the lived experience of class and its wider structuring. This took place in a relatively broad and open sub-discipline where sociology, labour studies and anthropology intersect with area studies. In some cases, like that of Simon Clarke on Russia, talented native researchers made co-investigations more fruitful. Other examples in this line are (mainly limiting our scope to Anglophone scholarship for convenience) Claudio Morrison (2008) and Sarah Ashwin $(1998,1999)$ who focussed on the postcommunist transition of relations in Russian industry - the decay of paternalism and the endless patience of workers in the 1990s. They also produced important insights into the kind of neoliberal reform imposed on these societies and how ordinary people responded and 'coped'.

More recently, in the 2000s, Elizabeth Dunn (2004), Chris Hann (2006), David Kideckel (2002, 2004, 2008) and Alison Stenning et al. (2010), among others, provided empirically rich, yet theoretically insightful and satisfying conceptions of particular forms of neo-capitalism and 
'domestications' of neoliberalism by workers in Poland, Hungary, Romania, Slovakia/Poland, respectively. Stenning et al. (2010) describe 'domestications' of neoliberalism in postsocialist communities, but more often their portrait is of enforced 'accommodation' - as those who could formerly reproduce the working-class household are forced into portfolio employment. Similarly, Kideckel (2002) stresses the 'unmaking' of a working class in Romania; the pace of 'neocapitalist' forces there lead to extreme declines in workers' fortunes.

A third wave studies work and class in post-socialist societies in an intersectional manner. This is not so much a cultural, as an ethnographic turn in the scholarship on post-socialist work, and more often involves native scholarship. Walker $(2009,2014)$ and Salmenniemi (2012) examine the intersection of class, work, youth, social mobility, gender, consumption and rural-urban migration in Russia, bringing a performative and interactionalist lens to analysis. Kesküla (2014) and Rotkirch et al. (2012), provide details of the actual organizational and relational processes of labour disembedding and alienation in the post-socialist period as well as documenting the encounter of transnational capital, post-socialist workers and re-embedding processes of governmentalization more closely. In addition, a new historicism of labour and working classes under late socialism is underway (Barta 2013), while others focus on the continuing salience in the present of nostalgia and memory - or mnemonic resources of class - intersecting with classed identities and the meaning of work (Levinson 2007; Schwartz and Morrison 2013).

Lem (2002: 287), writing on contemporary France, argues that class maintains its potency both as a subjective category and an analytical category despite processes of deindustrialization, and 'remains indispensable to understanding the nature of change in late capitalism'. But what of post-socialist societies where social and economic transformation has occurred in little more than a generation? Some key questions around class arise from new forms of precarity that workers face after social 
state withdrawal in post-communism (Artiukh 2015, Nedbálkova 2015, Mrozowicki 2011). This is experientially refracted through the living memory of the socialist period - particularly in urban spaces where generations of workers have lived, even if these places have suffered rapid deindustrialisation.

At the same time some CEE states have recently experienced new forms of neoliberal patch-work reindustrialisation, as transnational corporations relocate production to what are now low-wage countries attached to the core. Workers are therefore a key 'pinch point' in the current stage of the globalisation of capital, the spread of governmental neoliberalism, and therefore a mine of sociological data on a possible future for the 'West': societies stripped of most pretences of social democracy, the welfare state, workplaces less mediated by pretences of industrial relations, typified by low social mobility, high inequality, and a growing informal economy and other symptoms of precarity. These factors offer promising themes to work on, which can be roughly divided into the following areas.

\section{Spaces of work and workers}

Recently, scholars have focussed on the legacy of the 'company town' or monotown for the present workers as they struggle with economic transformation. Many take their cue from Stephen Kotkin's labour history, Magnetic Mountain (1995), a rich portrait of the total social institution factory town under Stalinism - but which also shows how workers' articulation of a social contract with the state emerges in this space and time - along with social mobility, despite the coercive nature of the Soviet factory. 
Alison Stenning et al. (2010) put the emphasis on 'coping' and managing by workers who are at the sharp end of market-led reform: 'domesticating neoliberalism' explains how Polish and Slovak worker families deal with the loss of jobs and their new status as 'working poor'. The major contribution of this study is the satisfyingly complete account of placeness - the massive high-rise housing estates of Krakow and Bratislava that retain a working-class identity and serve as some kind of basis of survival in social networking and mutual aid in the present. Deindustrialisation of space is connected to the lived dimensions of classed communities that continue after the factory. There are other recent treatments of the company town highlighting placeness and the continuity of industrial and class identities in the present across Eurasian post-socialist states (Tkach 2008, Pelkmans 2013, Kesküla 2014, Rajkovic 2015, Morris 2016).

\section{Memory - the past in the present}

As can be seen from some of the research cited earlier, there is a tendency, even in work sensitive to the personhood of workers, to focus on victimhood - for good reason. Vaccaro (2006) writing on the deindustrialised Spanish Pyrenees, notes that while social memory among groups subject to loss of status and livelihood can fall into nostalgia - a category widely explored in post-socialism - it is equally important to avoid pervasive essentializations of the 'lack of options for the local populations in the face of these changes. Local agency, however, manifests itself in many ways: resistance, transformation, negotiation, connivance or denial' (372). Memory studies are important in highlighting the ongoing articulation of class in the present in terms of the past whether in terms of dignity in work or the social wage (Schwartz 2015; Straughn 2009). For example, Smolyak (2014) examines the changing meaning of factory gleaning and 'resource theft' for DIY practices in the past and present in Russia. Always key to the maintenance of social networks, DIY linked professional identity, pride in work and particularly socialist forms of ownership. Now, with limited 
access to factory resources, DIY bespeaks inequality. An attention to the longue durée of class identity also questions whether late capitalism represents radical breaks and disjunctures. The temporal and more agency-focussed approaches reflect a wider shift towards biographical and oral histories (Raleigh 2012). These use autobiographical narratives, written memories and the like to better understand the dynamic of social transformation in Eastern Europe and the biographical 'consequences' of class disembedding (e.g. Golczynska-Grondas and Potoczna 2015).

\section{Actually-lived experience of class - and future avenues for research}

Insightful research on working-class agency pays attention to place and memory, but also to temporal continuities and changes: what workers 'do' and 'make' - whether they remain in formal normative employment or are pushed into the margins in the informal economy, subsistence farming, or white-collar service work - experienced as both downward and upward mobility (Walker 2014, Morris 2016). Other examples in the line of apprehending class in the present are studies on 'invisible citizens' (informal day labourers and the unemployed) in Lithuania (Harboe Knudsen 2014), the 'normalisation of precarity' among youth in Poland (Mrozowicki 2011), class, gender and biopolitics in Russia (Salmenniemi and Adamson 2014), and class-based domestic and care work (Rotkirch et. al. 2012; Kovács 2014).

Much current work on marginalised people is concerned with a post-socialist understanding of precarity that cuts across class structures. Workers in postsocialist states are the groups most enmeshed in new forms of capitalist relations. Debates continue about the relative degrees of entrepreneurial self-remaking associated with neoliberal governmentality, or even whether, given the rapid industrialisation of part of Eurasia in the socialist period, older, peasant identities remain informative of class identities (Peacock 2012). At the same time we should take a leaf from those 
who use the example of the Global South to challenge not only the position that class is no longer relevant, but also question the 'marginality paradigm' along with precaritization more generally (Munck 2013). As post-socialist societies are sites of ever-more intensive exploitation by transnational corporations, a re-proletarianization approach may be just as apt as the deindustrialisation one. This logic is compounded by relative ethnic homogeneity that remains in working-class communities (Ost 2015). As the transnational factory and post-socialist workers encounter each other, what will be the results in terms of resistance and reaction, given the socialist inheritance? Will it be continued atomisation or articulation?

Post-socialist workers are 'present' at their own making - i.e. subjectively responsive to continuity and change in their reinscription as workers (Krinsky 2007). Scholars have the opportunity to observe work and class discursively, as much as an ontologically, showing when and how 'class happens', and how class patterns social action (Therborn 2002: 223). Just as postsocialist transformation cannot be seen to have an end point, class relations in Eastern Europe and Eurasia are ongoing processes. They are neither statically objective, neither are they completely openended; 'but are constrained, shaped — and recursively shape — the political and social worlds in which they occur.' (Krinsky 2007: 344). Helemäe and Saar (2013: 54) argue that this makes postsocialist societies extraordinary laboratories for testing both existing theories and elaborating new ones on class (Eyal et al. 2003). They present the opportunity to challenge and develop knowledge (cf. Stenning and Hörschelmann 2008).

Lem's critique (2002: 301) of the neglect of class by postindustrial theorists in the West is instructive to the post-socialist context and relevance of class: 'the presence of new kinds of workers in new kinds of enterprises, in contexts that involve increasingly political and cultural complexity, with the emergence of nationalism and regionalism, does not necessarily imply the 
elimination of subjectivities that express such class divisions.' While the mainstream marginalization of class discourse continues in these societies and influences perhaps most of all workers themselves, whose class consciousness and identity remain 'underdeveloped' (Helemäe and Saar 2012: 54), this 'repression' leads to unpredictable political effects such as neo-nationalist populism (Kalb 2011: 14). Populism in Eastern Europe as a 'return of the repressed' anticipates unresolved issues in the burial of class analysis in the West too, particularly since the 2008 global financial crisis. The ongoing trauma of working-class experience in postsocialist societies, in this sense, needs to be comparatively appreciated as just a more extreme, brutal, and rapid version of the processes of labour disembedding in the West (just as urbanisation and industrialisation were in the socialist period). Kalb links rapid and extreme forms of 'primitive accumulation' and new class formations associated with this in CEE with the rise of right-wing populism and a 'displaced version of working-class politics' (Žižek 2008: 267, in Kalb 2012: 14-15). The newly exploited are left to their 'depleted informal and sometimes criminal shadow economies' (Kalb 2011: 18). They are too easily reimagined as the dangerous opponents of civil society and democratization, thus justifying their absence in serious sociological inquiry, despite the fact that it is workers who are best qualified for an immanent critique of new forms of marketized social relations. Kalb concludes, 'Ironically, therefore, the post-socialist East allows us to tell the West about class again [...] [T]his alerts us to the possibility that other driving forces, more straightforwardly associated with the making, unmaking, and restricting of class, may be the more fundamental ground from which xenophobia as a politically driven process gets its support base in the West' (2011: 18-19). Thus sociological sensitivity to the experience of class and class analysis in the East is instructive of the continued need and importance of 'Working-class Studies' in general. This entails an analysis of 'working class lives as complex and embodied practices played out in a wide variety of spaces, neither reified nor vilified, but explored and analysed' (Stenning 2005: 993, in Dowling 2009: 837). 
References:

Alasheev, S. 1995a. Informal Relations in the Soviet System of Production. In Clarke, S., (ed.) Management and Industry in Russia: Formal and Informal Relations in the Period of Transition. Cheltenham: Edward Elgar, 29-71.

. 1995b. On a Particular Kind of Love and the Specificity of Soviet Production. In Clarke S., (ed.), Management and Industry in Russia: Formal and Informal Relations in the Period of Transition. Cheltenham: Edward Elgar, 72-98.

Alasheev, S., and Kiblitskaia, M. 1996. How to survive on a Russian's Wage. In Clarke, S. (ed.) Labour Relations in Transition: Wages, Employment and Industrial Conflict in_Russia. Cheltenham: Edward Elgar, 99-119.

Artiukh, V. 2015. Taming the Labor: Class Genesis of Lukashenka Regime. European Sociological Association Conference Paper. 12th Conference of the European Sociological Association 2015, 25-28 August, RN6 Critical Political Economy, ID: 4744.

Ashwin, S. 1998. Endless Patience: Explaining Soviet and Post-Soviet Social Stability. Communist and Post-Communist Studies, 31(2), 187-198.

. 1999. Russian workers: the anatomy of patience. Manchester University PressUK.

Barta, E. 2013. Alienating Labour: Workers on the Road from Socialism to Capitalism in East Germany and Hungary. New York and Oxford: Berghahn.

Bibkov, A. 2012. Metodologiia issledovanii "vnezapnogo" ilichnogo aktivizma (rossiiskie mitingi I ulichnye lagaria, dekabr' 2011 iiun' 2012. Laboratorium: Russian Review of Social Research 2. http://cyberleninka.ru/article/n/metodologiya-issledovaniya-vnezapnogo-ulichnogo-aktivizmarossiyskie-mitingi-i-ulichnye-lagerya-dekabr-2011-iyun-2012-1. (Accessed 9 November 2015).

Blinnikov, M., Shanin, A., Sobolev, N., and Volkova, L. 2006. Gated communities of the Moscow green belt: newly segregated landscapes and the suburban Russian environment. GeoJournal 66(1): 65-81. 
Boyadjieva, P and Kabakchieva, P. 2015. Inequality in Poverty Bulgarian Sociologists on Class and Stratification. East European Politics and Society 29(3): 625-639.

Burawoy, M. 2001. Neoclassical Sociology: From the End of Communism to the End of Classes. American Journal of Sociology 106(4): 1099-1120.

Burawoy, M. with J. Lukács, 1992. The Radiant Past: Ideology and Reality in Hungary's Road to Capitalism. Chicago: Chicago University Press.

Caldwell, M. 2004. Not by Bread Alone: Social Support in the New Russia. Berkeley, CA: University of California Press.

de Certeau, M. 1984. The Practice of Everyday Life. trans. Steven Rendall, Berkeley: University of California Press.

Clarke, S. 1995. Management and Industry in Russia: Formal and Informal Relations in the Period of Transition. Cheltenham: Edward Elgar..

Crowley, S., and Ost, D. (eds.) 2001. Workers after workers' states: Labor and politics in postcommunist Eastern Europe. Lanham, Maryland and Oxford: Rowman and Littlefield.

Dowling, R. 2009. Geographies of identity: landscapes of class. Progress in Human Geography 33(6): 833-839.

Drahokoupil, J. 2015. Class in Czechia: The Legacy of Stratification Research. East European Politics and Society 29(3): 577-587

Dunn, E. C. 2004. Privatising Poland: Baby Food, Big Business, and the Remaking of Labor. Ithaca, NY: Cornell University Press.

Edele, Mark. 2007. Soviet Society, Social Structure, and Everyday Life: Major Frameworks Reconsidered. Kritika: Explorations in Russian and Eurasian History 8(2): 349-373.

Edwards, J., Evans, G., and Smith, K. 2012. Introduction: The middle class-ification of Britain. Focaal-Journal of Global and Historical Anthropology 62 (2012): 3-16.

Eyal, G., Szelényi, I. and Townsley, E. 1998. Making Capitalism Without Capitalists : Class Formation and Elite Struggles in Post-Communist Central Europe. London: Verso. 2003. On Irony: An Invitation to Neoclassical Sociology, Thesis Eleven 73: 5-41.

Fabo B. 2015. Rediscovering Inequality and Class Analysis in Post-1989 Slovakia. East European Politics and Societies and Cultures 29(3) 588-597.

Filippov, A. 2013. Sovetskaia sotsiologiia kak politseiskaia nauka. Novoe Literaturnoe Obozrenie 123. http://magazines.russ.ru/nlo/2013/123/6f.html. (Accessed 9 November 2015).

Filtzer, D. 1992. Soviet Workers and De-Stalinlization. Cambridge University Press. 
. 1996 'Labor Discipline, the Use of Work Time, and the Decline of the Soviet System,' International Labor and Working-Class History 50: 9-28.

Golczynska-Grondas, A. and Potoczna, M. 2015. Systemic transformation "loosers" [sic] biographical experiences of social welfare clients in post-industrial Polish city. European Sociological Association Conference Paper. 12th Conference of the European Sociological Association 2015, 25-28 August, RN03 Biographical Perspectives on European Societies, S02 / The Process of Transformation in East European Countries in the Everyday Experiences of their Ordinary Citizens.

Grigoryeva, A. 2015. Parachuting in: class and internal colonialism in Moscow's anti-Putin protests. Paper at ASA15: Symbiotic anthropologies, Exeter, UK.

Harboe Knudsen, I. 2014. The Story of Šarūnas : An Invisible Citizen of Lithuania. in The Informal Post-Socialist Economy: embedded practices and livelihoods. Eds. Jeremy Morris and Abel Polese. London and New York: Routledge, pp. 35-51.

Hann, C. 2006. 'Not the Horse We Wanted!': Postsocialism, Neoliberalism, and Eurasia. Münster: LIT Verlag.

Haraszti, M. 1977. A Worker in a Worker's State: Piece-Rates in Hungary, trans. by Michael Wright Harmondsworth and New York: Penguin.

Hass, J. K. 2013. Review of Rethinking Class in Russia. Ed. Suvi Salmenniemi. Burlington, Vt.: Ashgate, 2012. xiv, 270 pp. Notes. Bibliography. Index. Tables. \$114.95, hard bound. Slavic Review 72(4): 926-928.

Helemäe, J., Saar, E. 2013. Estonia - Highly Unequal but Classless? Studies of Transition States and Societies 4. http://publications.tlu.ee/index.php/stss/article/view/96 (Accessed 9 November 2015).

. 2015. Estonia: Visible Inequalities, Silenced Class Relations. East European Politics and Society 29(3): 565-576.

High, S. 2013. Beyond Aesthetics: Visibility and Invisibility in the Aftermath of Deindustrialization. International Labor and Working-Class History 84: 140-153.

Hinz S and Morris, J. 2016. Trade Unions in Transnational Automotive Companies in Russia and Slovakia: Prospects for Working class power. European Journal of Industrial Relations. Onlinefirst

Holubenko, M. 1975. The Soviet Working Class: discontent and opposition. Critique: Journal of Socialist Theory 4(1): 5-25.

Hornsby, R. 2013. Protest, Reform and Repression in Khrushchev's Soviet Union. Cambridge University Press.

Joseph, J. 2013. Resilience as embedded neoliberalism: a governmentality approach. Resilience 1:1, $38-52$. 
Kalb, D. Introduction: Headlines of Nation, Subtexts of Class: Working-Class Populism and the Return of the Repressed in Neoliberal Europe. In Don Kalb and Gabor Halmai (eds.) Headlines of Nation, Subtexts of Class: Working-Class Populism and the Return of the Repressed in Neoliberal Europe. New York and Oxford: Berghahn Books, pp. 1-36.

Kenney, P. 1997. Rebuilding Poland: Workers and Communists, 1945-1950. Ithaca, N.Y.: Cornell University Press.

Kesküla, E. 2014. Disembedding the Company from Kinship: Unethical Families and Atomized Labor in an Estonian Mine. Laboratorium: Russian Review of Social Research, 2: 58-76.

Kideckel, D. A. 2002. The Unmaking of an East-Central European Working Class. In C. Hann (ed.) Postsocialism: Ideals, Ideologies and Practices in Eurasia. London: Routledge, pp. 114-32. 2004. Miners and Wives in Romania's Jiu Valley: Perspectives on Postsocialist Class, Gender, and Social Change. Identities 11: 39-63. 2008. Getting by in Postsocialist Romania: Labor the Body and Working-Class Culture. Indiana University Press: Bloomington and Indianapolis.

Konrád, G. and Szelényi, I. 1979. The Intellectuals on the Road to Class Power: A Sociological Study of the Role of the Intelligentsia in Socialism. San Diego: Harcourt Brace Jovanovich

Kotkin, S. 1995. Magnetic Mountain: Stalinism as a Civilization. Berkeley: University of California Press.

Kovács, B. 2014. Nannies and informality in Romanian local childcare markets. In Morris, Jeremy and Abel Polese (eds.) The Informal Post-Socialist Economy: Embedded Practices and Livelihoods. London and New York: Routledge, pp. 67-84.

Krinsky, J. 2007. Constructing Workers: Working-Class Formation under Neoliberalism. Qualitative Sociology 30(4):343-360.

Kustarev, A. 2013. Mifologiia sovetskogo proshlogo. Neprikosnovennyi zapas, 3.89, $<$ http://magazines.russ.ru/nz/2013/3/1m-pr.html> [accessed 9 November 2015].

Lazić, M.,and Cvejić, S. 2010. Working class in post-socialist transformation: Serbia and Croatia compared. Corvinus Journal of Sociology and Social Policy 1(1): 3-29.

Lem, W. 2002. Articulating Class in Post-Fordist France. American Ethnologist 29(2): 287-306.

Levinson, A. 2007. O tom, kak rabochie na nashikh zapadnykh zavodakh mechtaiut vernut'sia v VPK. Otechestvennye zapiski 4. http://demoscope.ru/weekly/2008/0337/analit03.php. (Accessed 9 November 2015).

Mah, A. 2012. Industrial Ruination, Community, and Place: Landscapes and Legacies of UrbanDecline. Toronto: University of Toronto Press.

Marzec, W., and Zysiak, A. 2016. Days of Labour: Topographies of Power in Modern Peripheral Capitalism. The Case of The Industrial City of Łódź. Journal of Historical Sociology, 29(2): 129159. 
McMillan, Chris. 2013. Žižek and Communist Strategy: On the Disavowed Foundations of Global Capitalism. Edinburgh: Edinburgh University Press.

Morris, J. 2016. Everyday Post-Socialism: Working-Class Communities in the Russian Margins. Basingstoke: Palgrave.

Morrison, C. 2008. A Russian Factory Enters the Market Economy. London and New York: Routledge.

Morrison, C. and Bizyukov, P. 2016. Informal and uncertain: employment relations through the broken mirror of Russian social sciences. Work, Employment and Society. in press.

Mrozowicki, A. 2011. Coping with Social Change: Life Strategies of Workers in Poland's New Capitalism. Leuven: Leuven University Press.

Munck, R. 2013. The Precariat: A view from the South. Third World Quarterly 34(5): 747-762.

Nedbálková, K. 2015. Working Class in Precarious Times (the Czech Republic case). European Sociological Association Conference Paper. 12th Conference of the European Sociological Association 2015, 25-28 August, RN6 Critical Political Economy, ID: 4455.

Ness, I. 2016. Southern Insurgency: The Coming of the Global Working Class. London: Pluto Press.

Outhwaite, W. 2007. Bourdieu and Postcommunist Class Formation. Sociological Research Online 12(6)10. <http://www.socresonline.org.uk/12/6/10.html>

Ost, D. 2009. 'he invisibility and centrality of class after communism. International Journal of Politics, Culture and Society 22: 497-515. . 2015. Class after Communism: Introduction to the Special Issue. East European Politics \& Societies 29(3): 543-564.

Ost, D., and Gagyi, A. 2015. Panel: A Return of Critical Class Analysis in Eastern Europe? European Sociological Association Conference Panel. 12th Conference of the European Sociological Association 2015, 25-28 August.

Peacock, E. A. 2012. The Authentic Village and the Modern City: The Space-Time of Class Identities in Urban Western Ukraine. Anthropology of East Europe Review 30(1): 213-236.

Pelkmans, M. 2013. Ruins of hope in a Kyrgyz post-industrial wasteland. Anthropology Today, 29: $17-21$.

Pittaway, M. 2012. The Workers' State: Industrial Labor and the Making of Socialist Hungary, 1944-1958. Pittsburgh, PA: University of Pittsburgh Press.

Polanska, D. V. 2010. Gated Communities and the Construction of Social Class Markers in Postsocialist Societies: The Case of Poland. Space and Culture 13(4) 421-435.

Pozniak, K. 2014. Nowa Huta: Generations of Change in a Model Socialist Town. Pittsburgh: University of Pittsburgh Press. 
Rajkovic, I. 2015. Struggles for Moral Ground: Problems with Work and Legitimacy in a Serbian Industrial Town. Unpublished PhD Dissertation, University of Manchester.

Raleigh, D. J. 2012. Soviet Baby Boomers: An Oral History of Russia's Cold War Generation. Oxford University Press.

Rivkin-Fish, M. 2009. Tracing landscapes of the past in class subjectivity: Practices of memory and distinction in marketizing Russia. American Ethnologist 36(1): 79-95.

Rotkirch, A., Tkach, O., and Zdravomyslova, E. 2012. Making and Managing Class: Employment of Paid Domestic Workers in Russia. In Salmenniemi, Suvi. (ed.) 2012. Rethinking Class in Russia. Farnham Surrey, Burlington VT.: Ashgate, pp. 129-148.

Salmenniemi, S. (ed.) 2012. Rethinking Class in Russia. Farnham Surrey, Burlington VT.: Ashgate.

Salmenniemi, S., and Adamson, M. 2014. New heroines of labour: Domesticating postfeminism and neoliberal capitalism to Russia. Sociology 49: 188-105.

Schwartz, G. 2015. Remembering the new Working Class: Memorial and Material Transformations in the making of the Post-Soviet World. European Sociological Association Conference Paper. 12th Conference of the European Sociological Association 2015, 25-28 August, RN6 Critical Political Economy, ID: 1286.

Schwartz, G., and Morrison, C. 2013. Collective Memory and the Re(dis)covery of Class in PostSoviet Work Organisations. BSA Work Employment and Society Conference, Coventry, United Kingdom.

Siegelbaum, L. H. 1988. Stakhanovism and the Politics of Productivity in the USSR, 1935-1941. Cambridge University Press.

Siegelbaum L. H., and R. G. Suny, eds., 1994. Making Workers Soviet: Power, Class and Identity. Cornell University Press: Ithaca, N.Y.

Smolar, A. 1996. From Opposition to Atomization. Journal of Democracy 7(1): 24-38.

Smolyak, O. 2014 'Working for Yourself': Resource Theft at a Factory in the Late Soviet Era. Laboratorium: Russian Review of Social Research 6(2): 21-57.

http://www.soclabo.org/index.php/laboratorium/article/view/418/1110. (Accessed 9 November 2015).

Stenning, A. 2005. Where is the Post-Socialist Working Class? Working-class lives in the spaces of post-socialism. Sociology 39(5): 983-999.

Stenning, A., and Hörschelmann, K. 2008. History, Geography and Difference in the Post socialist World: Or, Do We Still Need Post-Socialism? Antipode 40(2), 312-335.

Stenning, A., Smith, A., Rochovská, A. and Swiatek, D. 2010. Domesticating Neo-Liberalism: Spaces of Economic Practice and Social Reproduction in Post-Socialist Cities. Malden, MA: Wiley-Blackwell. 
Straughn, J. B. 2009. Culture, Memory, and Structural Change: Explaining Support for "Socialism" in a Post-Socialist Society. Theory and Society, 38: 485-525.

Straus, K. M. 1997. Factory and Community in Stalin's Russia: The Making of an Industrial Working Class. Pittsburgh University Press.

Therborn, G. 2002. Class Perspectives: Shrink or Widen? Acta Sociologica 45(3): 221-225.

Tkach, O. 2008. Zavodskaia dinastiia kak sotsial'no-kul'turnyi fenomen: Sovetskii i postsovetskii periody. Avtoreferat na soiskanie uchenoi stepeni kandidata sotsiologicheskikh nauk. Saint Petersburg: Sotsiologicheskii institut Rossiiskoi Akademii Nauk.

Tóth, A. N.d. Workers as Life Entrepreneurs. Unpublished draft article. Available athttps://www.academia.edu/24903671/Workers_as_life-entrepreneurs

Triska, J. F. and Gati, C. (eds.) 1981. Blue Collar Workers in Eastern Europe. London: George Allen \& Unwin.

Trubina, E. 2013. Primiriaias's upadkom: ruiny 2.0. Neprikosnovennyi zapas, 3(89). (http://magazines.russ.ru/nz/2013/3/14t.html). (Accessed 9 November 2015).

Verdery, K., Bernhard, M., Kopstein, J., Stokes, G., and Kennedy, M. D. 2005. Rereading "The Intellectuals on the Road to Class Power". Theory and Society 34(1): 1-36.

Walker, C. 2009. From 'inheritance' to individualization: disembedding working-class youth transitions in post-Soviet Russia. Journal of Youth Studies 12(5): 531—545.

. 2014. 'I don't really like tedious, monotonous work': working-class young women, service

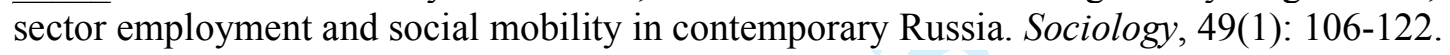

Zebrowski, C. 2013. The nature of resilience. Resilience 1:3, 159-173.

Žižek, S. 2008. In Defence of Lost Causes. London: Verso.

Zubarevich, N. 2009. Kak spasti monogoroda? I nado li. Chetverg. 24 August 2009. http://www.kchetverg.ru/2009/08/24/kak-spasti-monogoroda-i-nado-li/ (Accessed 9 November 2015).

2011. Chetyre Rossii. Vedomosti.ru. 30.12.2011, http://www.vedomosti.ru/opinion/news/1467059/chetyre rossii (Accessed 9 November 2015). 